\title{
The reform of collective forest rights in China and Its implementation in the Fushun City Region
}

\author{
S. Jiang, B.J. Lewis, L. Dai, W. Jia, Y. An
}

Jiang S., Lewis B.J., Dai L., Jia W., An Y., 2014. The reform of collective forest rights in China and Its implementation in the Fushun City Region. Ann. For. Res. 57(2): 319-332, 2014.

Abstract. The paper provides an historical overview of the gradual but erratic evolution of collective forest rights in the People's Republic of China. Forest tenure rights have been subject to numerous changes since the establishment of People's Republic in 1949. In the most recent decades, use rights for forests have been transferred from collective to individual household-based with the intent to provide benefits to forest farmers. The implementation of the intended reforms has varied considerably from one province to another, with the majority of reform efforts originating in the southern provinces. This article looks at the major effort undertaken in Northeast China. The Fushun collective forest rights reform was analyzed using data obtained through field investigation by the Fushun Forestry Bureau. Initial effects of reform in terms of modes of rights assignment and farmer motivations to conduct forest management activities, as well as farmers' income and financing conditions, are discussed. Remaining significant challenges are also briefly considered. Keywords Northeast China, collective forests, forest land tenure, forest use rights, Fushun City.

Authors. Shengwei Jiang - Institute of Applied Ecology, Chinese Academy of Sciences, 72 Wenhua Rd., Shenyang, PRC 110016; Forestry Department of Liaoning Province, No.2 North Taiyuan Street, Shenyang, PRC 110001; Bernard J. Lewis (LewisBern@Gmail.com), Limin Dai - Institute of Applied Ecology, Chinese Academy of Sciences, 72 Wenhua Rd., Shenyang, PRC 110016; Weiwei Jia - College of Forestry, Northeast Forestry University, No. 26 Hexing Rd., Harbin, PRC 150040; Yingfeng An - College of Biosciences and Biotechnology, Shenyang Agricultural University, No. 120 Dongling Rd., Shenyang, PRC 110161.

Manuscript received June 09, 2013; revised August 01, 2014; accepted August 04, 2014; online first August 11, 2014.

\section{Introduction}

China's transformation into an economic power over the past quarter century has been a unique world phenomenon. To cite one example, the extreme poverty rate $(<\$ 1.25 /$ day $)$ 
has declined from $85 \%$ in 1981 to $16 \%$ in 2005 (World Bank 2013). At the same time, this transformation has not come without costs, among the most noteworthy being the intense pressure placed upon and significant degradation of the country's environment, including the country's 200 million hectares of forests. Throughout this period, efforts to sustain the forest resource have continued, but have often been overwhelmed by economic pressures.

As reported by the $7^{\text {th }}$ National Forest Inventory, $39.4 \%$ of the total Chinese forest area is State-owned. Collectively-owned forests account for $32.1 \%$ of the total forest area, while private forests - those whose resources (but not the land itself) are owned by individual households or mixed shareholding groups account for $21.7 \%$ of the total forest area (SFA 2009). Collectively-owned forests dominate in the south and State-owned forests are most prevalent in the north. Liaoning is the only one of the four Northeast provinces in which more than half of total provincial forest lands are collectively-owned. Collective owners may be townships, or more typically administrative villages or village household groups. With respect to collective forests, major efforts have been underway since the turn of the century with the ultimate goal of dismantling collective management and transferring forest use rights to individual households. Such changes in tenure arrangements have economic, social and political implications, and it is recognized that the decentralization of forest management in China has not always led to improvements in forest management and rural livelihoods (FAO 2009). At the same time, secure tenure arrangements, including expanded rights to trees and other forest resources, can provide farmers with a more stable foundation upon which decisions to engage in viable forest management activities may rest; and whether these occur in turn will ultimately affect the long term ecological viability of the forest resource (Wang et al. 2007, Olsson et al. 2004).

The objectives of this article are: (i) to pro- vide an overview of how the reform of forest rights has occurred in China in recent decades; (ii) to describe the efforts undertaken by the Fushun City Forestry Bureau in Northeast China to reform the forest tenure system and transfer use rights to individual households; (iii) to assess the initial results of the Fushun effort in light of the overall context of the history of forest rights reform in China.

The article first considers the limited but increasing research efforts devoted to forest land tenure and associated property rights in China. This is followed by an overview of the history of forest land tenure and management in China, in effect situating the challenge faced by the Fushun Bureau of integrating its reform effort within the historical context of tenure insecurity experienced by China's rural population. Attention then turns to the approach to tenure reform taken by the Fushun City Forest Bureau, adopted with the aid of broad guidelines issued by the central government. Elements and administration of the tenure reform program in Fushun City are reviewed, as are the program's initial accomplishments. The article concludes with a cautious note of optimism as to how these efforts may contribute to both the social welfare of the rural population as well as the ecological integrity and sustainable management of China's forest resources.

\section{Forest tenure reform - a challenging research topic in China}

Land tenure may be defined as the set of institutions and policies that determine locally how the land and its resources are accessed; who can hold and use these resources; and for how long and under what conditions they may be used (Naughton-Treves and Day 2012). For collectively-owned lands in China, the decision-making authority, typically one or more villages, can decide whether and how to distribute use rights for residence, farming, forest uses, and other purposes to farmers or other 
individual households. Such use rights fall within the broader domain of property rights, recalling Demsetz's classic article in the field (1967) which describes property as a 'bundle of rights' pertaining to the control, ability to derive income from, and the transfer of property. Schlager and Ostrom (1992) elaborated on this idea, identifying basic rights pertaining to property in terms of access, exclusion, withdrawal (of products from the resource), management (in the sense of regulating use patterns and transforming the resource), and alienation (selling or leasing the resource).

With the above distinctions in mind, 'tenure reform' in this article basically refers to the reassignment of rights other than ownership of land. In China, the State maintains ownership of all land as the bedrock of State control. The major feature of land ownership is the right to alienate - i.e., sell or otherwise dispose of the land. With the exception of the right to alienate that belongs to the State, all other rights could theoretically be transferred from the collective to individual households.

Research on property rights, and in particular land tenure, in China was quite limited prior to the turn of the century, often being addressed in passing in studies of reform policies or institutional changes or treated as background assumptions in various policy analyses (Walder \& Oi 1999). Results of the first major effort to synthesize research on property rights in China were released in 1999 (Oi \& Walder 1999). The focus of this work was exclusively on rights related to State enterprises. Rights addressed included those related to management control of enterprises, the right to income flows therefrom, the right to assign ownership to other parties, and how the above rights were specified and enforced. Five types of ownership arrangements were examined - traditional State or collective ownership; management incentive contracts; government-managed partnerships; leased public assets; and privatization (Oi \& Walder 1999).

With respect to forest land, the major re- search effort emerged following the 2003 policy statement of the central government encouraging provinces to experiment with land tenure reform. Between 2006 and 2007, the Environmental Economics Program of Peking University (EEPC), with funding from the World Bank, the Ford Foundation, the Rights and Resources Initiative (Washington, D.C.) and support from the State Forestry Administration of China, conducted the first largescale, quantitative analysis of the forest tenure reforms in China to date, focusing on the period from 2000-2006. Two surveys covered more than 3000 randomly selected households in 288 randomly selected villages in 8 provinces where a majority of the forest is collectively owned. Again these provinces were all located in Southern China, with the notable exception that Liaoning province in Northeast China was also included. The surveys gathered information on demographic, economic and social characteristics of villages, as well as land management practices and any tenure reforms efforts that had been conducted to date.

Results from this study found that from 2000 to 2006 villagers across the eight surveyed provinces reduced collectively managed forests by about $2.5 \%$ (Xu et al. 2010). Individual household management increased in four provinces, including Liaoning. In that province slightly more than half of surveyed households were found to have rights defined in terms of individual household tenure, while $7 \%, 3 \%$, and $12 \%$ held tenure in the form of partnerships, village clusters, or contracts to outsiders, respectively. This left $23 \%$ of surveyed households with forests under strict collective management. However, the study remarked that, surprisingly, given the government rhetoric on land reform, there had not been a stronger shift towards household-based forest tenure arrangements in the six-year period covered by the survey. While household-based tenure increased in 7 of the 8 provinces, only an average of about $7 \%$ of collective forests was reallocated to other tenure types (Xu et al. 2010). 
The above study concluded that while the full effects of these initial reforms on land ownership, livelihoods and local governance remain undetermined, the reforms offered encouragement and potential for increasing incomes, accelerating reforestation, and reducing conflicts emanating from unstable and often ambiguous situations with respect to forest land tenure. It also cautioned, however, that a next 'generation' of reforms will be needed both to protect households from more powerful actors at the local level and to enable them to access credit markets as a tool for increasing production and enhancing incomes (Xu et al. 2010).

\section{An overview of the history of forest land tenure in the People's Republic of China}

The evolution of forest land tenure and management in China since the establishment of the People's Republic in 1949 is uneven and sporadic. Table 1 presents the succession of different laws and resolutions affecting the nature and structure of forest rights that have emanated from the central government over the course of the country's history. Forest land reforms have historically followed those in the agricultural sector, which has always set the pace since the trend for tenure liberalization begun in the 1980's. Three distinct periods can be identified along the historical evolution of forest tenure since the establishment of the People's Republic of China.

\section{The first three decades (1949-1979)}

Land reform in China was initiated at the time the PRC was established in 1949. At that time lands owned by the many feudal landlords were distributed to farmers, with full ownership of agricultural and forest land accorded to households. In 1952, the Constitution of the PRC was adopted, and four categories of land ownership were sanctioned; in addition to state- and collective-owned lands, individual- and capitalist modes of ownership were also recognized (Table 1). This arrangement was short-lived, however, as almost immediately government emphasis shifted toward a more socialist management arrangement for private lands, with farmers officially encouraged to form cooperatives in managing household forest lands. By 1958, with the launch of Mao Zedong's 'Great Leap Forward,' individual (i.e., 'private') ownership of farmland and forests was no longer allowed, and management thereof was assigned to advanced cooperatives and ultimately, large communes. In effect, collective ownership became the sole alternative to State-owned land and forests. This dual categorization was ultimately embedded in the $2^{\text {nd }}$ Constitution of the PRC in 1975.

The 1958 campaign also included a national effort to spur industrialization. Dependent on fuelwood for their operation, more than a half a million furnaces for the production of iron and steel sprung up in villages across the country, consuming vast amounts of fuelwood and contributing to a major period of deforestation in the country. This was accompanied by an even-more disastrous agricultural failure and famine from 1958-1961 in which millions perished (Yang 2012). One consequence of this catastrophe for land tenure arrangements that occurred in 1962 was that the management of large communes and communal forests was shifted to smaller production teams. This marked a first step in the gradual devolution of forest tenure and management to lower levels than the broad commune, a trend which did not accelerate significantly until more than a decade later. At the same time, collective ownership remained the most prevalent form of agricultural and forest land and resource ownership until the end of the Mao era in the late 1970's.

The first three decades of the PRC were tumultuous in many ways, and among the many repercussions was the shaping of the mindset of the rural population with respect to forest land and resource tenure. For the broad shifts 
Table 1 Significant laws and policies related to forest tenure and use rights in the PRC: 1949-2010

\begin{tabular}{|c|c|c|}
\hline 1950 & Land Reform Law of PRC & $\begin{array}{l}\text { Confiscated lands to be converted to common land and } \\
\text { gradually distributed to peasants }\end{array}$ \\
\hline 1952 & $\begin{array}{l}\text { Constitution of the } \\
\text { People's Republic of China }\end{array}$ & $\begin{array}{l}\text { Stipulated that ownership of means of production included: } \\
\text { National (public); cooperative (collective); individual } \\
\text { laborer; capitalist }\end{array}$ \\
\hline 1953 & $\begin{array}{l}\text { Resolution on Developing } \\
\text { Agricultural Cooperatives }\end{array}$ & $\begin{array}{l}\text { Peasants should construct mutual aid teams to manage } \\
\text { forests; land still owned by individuals }\end{array}$ \\
\hline 1958 & $\begin{array}{l}\text { Resolution on Establishing } \\
\text { People's Commune in Rural Areas }\end{array}$ & $\begin{array}{l}\text { Means of production (land, forests, livestock, etc.) to be } \\
\text { managed by commune; individual ownership of land and } \\
\text { forests abolished \& replaced by collective ownership }\end{array}$ \\
\hline 1962 & $\begin{array}{l}\text { Revised Draft Law Guiding } \\
\text { Rural People's Commune }\end{array}$ & $\begin{array}{l}\text { Management of communal forests transferred to smaller } \\
\text { production teams }\end{array}$ \\
\hline 1975 & Constitution of the PRC $\left(2^{\text {nd }}\right)$ & $\begin{array}{l}\text { Individual \& capitalist ownership categories canceled; } \\
\text { only public and collective ownership remained }\end{array}$ \\
\hline 1981 & $\begin{array}{l}\text { Resolution on Issues Concerning } \\
\text { Forest Protection \& Development }\end{array}$ & $\begin{array}{l}\text { production responsibility system initiated: contracting of } \\
\text { use rights for collective forest lands to farmer households; } \\
\text { family plots: use rights for degraded forest lands and } \\
\text { ownership rights to trees on them allocated to households; } \\
\text { First issuance of property certificates }\end{array}$ \\
\hline 1984 & No. 1 Document of 1984 & $\begin{array}{l}\text { Officially distinguishes land use rights from land ownership; } \\
\text { Collective forest land use contract lengths: } 15-70 \text { years } \\
\text { Ownership and inheritance of planted trees }\end{array}$ \\
\hline 1984 & $\begin{array}{l}\text { Forest Law of the PRC } \\
\text { (amended 1998) }\end{array}$ & $\begin{array}{l}\text { Legalized use rights for forest lands and ownership to } \\
\text { forest products; lacked rules regulating such rights } \\
\text { Required issuance of a forest rights certificate to affirm } \\
\text { individual rights to forests and forest land; } \\
\text { Strict limits on harvesting privately-owned trees }\end{array}$ \\
\hline 2002 & Rural Land Contracting Law & $\begin{array}{l}\text { Farmers" land rights are specified as "contracting and } \\
\text { operation rights" to farmland, forests \& grassland } \\
\text { Rights to collective forestland may be allocated to } \\
\text { households for a term of } 30 \text { years or longer }\end{array}$ \\
\hline 2003 & $\begin{array}{l}\text { Decision on Accelerating } \\
\text { Forest Development }\end{array}$ & $\begin{array}{l}\text { Emphasizes stabilization of contracting relationships for } \\
\text { collective forest lands allocated to households; Restricts } \\
\text { collective seizure of such lands }\end{array}$ \\
\hline 2008 & $\begin{array}{l}\text { Guidelines on Fully Promoting } \\
\text { Collective Forest Tenure System } \\
\text { Reform }\end{array}$ & $\begin{array}{l}\text { Promoted nationwide reform of collective forest rights } \\
\text { system with goals: Innovate management structure; clear } \\
\text { ownership rights; regulate transfer system; ease tax burden }\end{array}$ \\
\hline
\end{tabular}

in policy outlined above were experienced as a constant stream of shifting arrangements that left little evidence of stabilizing over time. The tenure situation faced by the average farmer may best be exemplified by a description of the history of change regarding the ownership of fruit trees in a county in Yunnan province during this period: "Ownership ... was transferred from households to advanced cooperative in 1956 and further to commune in 1958; commune back to households in 1961; households to production team in 1969; production team to households in 1971; households to production team in 1977; and production team to households in the late 1970s" (Liu 2001). Such a pattern of policy shifts was common throughout 
the country, instilling a pervasive sense of insecurity among the rural population regarding forest land and resource tenure.

\section{The middle decades (1980-1999)}

It was in the following decade, under Mao's successor, Deng Xiaoping, that the first significant set of forest reforms in the PRC began to be implemented. While collective ownership of non-state forests remained in effect, the separation of use rights from land ownership began to crystallize. Reforms in agriculture that had led in the late 1970's to the emergence of household-based 'production responsibility systems' (PRS) were not only adopted nationally for agriculture in 1982, but also endorsed as appropriate for forest lands in the 1981 Resolution on Forest Protection \& Development. The PRS had ensured the eventual shift in agricultural land management from the collective to the farmer via the transfer of use rights to farmers on a contractual basis, while also allowing farmers to sell some of their crops at market prices. Economic historians have come to see the production responsibility system as the first of several 'marginal revolutions' that paved the way for China's ultimate transformation from an impoverished socialist economy to state-controlled capitalism and, eventually, the world's second-largest economy (Coase \& Wang 2012). It also exemplifies the manner in which forest tenure reforms were gradually enacted prior to the turn of the century - i.e., as extensions of those first introduced for agricultural farmlands.

By 1983, the aforementioned Resolution had allowed for use rights to collective forests to be allocated to households via contract, and for production responsibility systems to be introduced into household-based forest management operations. This could also be accompanied by the issuance of formal property certificates to which use rights would be applicable. Although this did not occur uniformly across the entire country and was accompanied by a great deal of uncertainty throughout the rural population regarding the actual status of their forest tenure and ownership rights, the process had begun and the mechanism was in place for lasting reform.

At the same time, to complement the newly sanctioned household-based management at a time when demand for timber was increasing rapidly, the government had significantly deregulated forest harvesting by the mid-1980s. Given the aforementioned rural mindset regarding tenure insecurity and the newfound opportunity for unconstrained harvesting, it is not surprising that a period of widespread deforestation followed soon thereafter. By 1984, the government rescinded its earlier relaxation of constraints and established strict regulatory controls on forest harvesting, which in a few years expanded to include harvest quotas, harvest and transport permits, and a monopoly on wood purchases by firms controlled by the forestry bureaus. That same year harvesting restrictions were included in the country's first Forest Law, which also gave legal status to use rights for forest lands (officially recognized as distinct from land ownership in the most prominent policy document of that same year) and to the ownership of forest products, albeit with little guidance as to their enforcement. These controls generally remained in effect throughout the 1990s.

By the end of the century, non-state forest lands remained collective property, but use rights to them, including ownership of trees and other resources thereon, had often been allocated to households. While the overall picture regarding forest tenure had evolved since earlier decades, the pace of diversification had slowed during the 1990s. Household-based tenure arrangements were more widespread in the Southern provinces than elsewhere; but geographic variations in adoption rates, with occasional instances where forest management had reverted to back to the collective from households, had not fully alleviated the longstanding lack of trust in the government's interest in or 
ability to effectively guarantee tenure security. Such concerns were exacerbated by the regulatory burden and market restrictions imposed on households with respect to forest management. By the early 2000s, resentment by farmers and villagers at strict regulatory controls, along with lingering suspicion regarding the viability of any tenure arrangements in which forest use rights were so restricted, had boiled over into public protests. This led to significant actions by the central and provincial governments intended to clarify and stabilize forest tenure arrangements and relax the severe constraints on the ownership and management of forest resources.

\section{The contemporary era (2000-present)}

As the new century dawned, some significant changes had already been underway for the forestry sector in China. Foremost among these was the establishment of a national forest classification system, introduced in 2000 and implemented nationally three years later, in which two major categories of forest lands were defined - commercial and ecological welfare forests (EWF) - the latter being so designated in order to protect the nation's natural forests, which had been severely depleted during the previous two decades of the country's economic expansion (Dai et al. 2009). Harvesting was prohibited or severely limited in EWFs, with the ironic effect that any collective forests that were classified as EWF were also now off limits to harvesting. This only served to further inflame the aforementioned public protests in the early 2000s.

In early 2000, the State Forest Administration began to encourage provinces to experiment with tenure reform. As of 2003, about 5 percent of the country's state-owned forests had been devolved to other types of management, including collective and private; while about $20 \%$ of collective forests had been devolved to private management (FAO 2009). Several Southern provinces, most notably Fu- jian and Jiangxi, had experimented with transferring use rights of forest lands to individual households, and successful results obtained there encouraged the CPC Central Committee and State Council to issue the "Decision on Accelerating the Development of Forestry" in 2003. Intended as a more explicit national-level policy framework, this broad policy focused on increasing forest production across China within a broader context of property rights reform.

The two major components of the Decision were that use rights for forest lands were formally recognized, and management rights were to become freely transferable. The announced reforms reached villages through various levels of government over a period of years. Encouraged by this national policy statement, more than 10 provinces have been implementing a new round of forest tenure reforms in village collectives since 2004. As described below, in 2005 Liaoning Province adopted collective forest right reforms based on the 2003 guidelines with central themes of "clear property rights, expand management rights, and regulate transfer of management rights." (General Office of Liaoning Government 2005). Liaoning was the first province in Northern China to initiate this reform.

By 2008 the future of China's forest lands had become the focus of national attention at the highest levels of government (Jiabao 2009). In that year the CPC Central Committee and State Council issued a rule specifically addressing the collective forest rights system on a nationwide basis. The current aim of reform efforts regarding collective forest rights is to clear established ownership, encourage active exercise of management rights, normalize forest land transfer procedures, reduce taxes, further enfranchise and develop forestry productivity, and promote change in traditional forestry to modern forestry (CPC Central Committee and State Council 2008). The government envisioned a 5-year period within which to complete the basic reform of clearing 
property rights and contracting forest lands to families, which is the core of the reform. When the 2008 policy announcement was issued, the reform program in Fushun City, initially guided by the 2003 Decision on Forest Development, was in full swing and the more refined guidelines were incorporated within ongoing efforts.

\section{Implementation of forest rights reform in Fushun City}

Among the four provinces of Northeast China, where State-administered forest lands are predominant, Liaoning is the only province in which collective forests represented more than half of all provincial forest lands. This was a major impetus for the adoption of forest rights reform in the region. While the collective reform movement was gaining steam in the south, Fushun City in Liaoning province took the lead in introducing forest tenure reform to the North-Eastern provinces.

\section{Carrying out the reform program}

In December of 2005, under the impetus of the national Decision on Forest Development issued in 2003 and the relevant requirements of the People's Government of Liaoning Province, Fushun City began a new round of collective forest rights reform. The Fushun City Forest Bureau (FFB), one of eight forestry bureaus in Liaoning province, was designated to administer the reform program. At that time most woodlands were managed by village committees, a subgroup of the village assembly. The latter consists of all village members over the age of 18; each individual on the village committee represents between 5-15 village households. The committee directed forest operations, management and disposal of forest products within the village. According to the government's tree cutting policy, village committees occasionally harvested timber, which was sold primarily to the market, except for a small amount of wood used for building village bridges and public welfare activities. Rights to harvest timber were allocated to individual households by the committee in strict accordance with a timber quota dictated by higher levels of government. In practice this meant that not all farmers who desire so may receive timber cutting rights each year. The committees generally only carried out simple forest management activities - e.g., tending, logging and some afforestation. Several villagers were usually hired as forest rangers, supervising a fixed area, while other villagers did not participate in forest management. Income from timber sales was controlled by the village committee and utilized mainly used for roads, bridges, sanitation and administrative expenses. When villagers desired to use wood, they had to purchase it from the village committee. The Fushun reform program has three major components (General Office of Liaoning Province 2005). First, use rights and ownership of trees and other resources on all collective forest lands (except those reserved as natural areas or subject to controversy over ownership, use rights, etc.) were to be distributed to farmer households, with the method of distribution (see below) to be selected by each household. The village would provide the official sanctioning of the assignment of rights. In this way, use and management rights previously controlled by the collective, as well as ownership of the trees and other forest resources on the land, were to be assigned to farmer households, households units, or other business entities. Secondly, farmers would now be allowed to plant trees and cultivate other products in their woodlands and retain ownership of such plantings. They could also actively manage their forests, and conduct other business activities, all of which may generate income for the farmer. Thirdly, farmers would now be able to formally transfer use rights to forest lands and to register any changes in forest rights over time, if they did so voluntarily and according 
to the law in a fair transaction. Such rights include ownership of planted trees and other forest crops. This measure is intended to provide the foundation for the establishment of a forest resource transfer market.

Under this reform effort there are four ways that collective forest resources may be assigned to farmers (Forestry Bureau of Fushun City [FFB] 2011): (i) Free or with a small contract fee charged during the assignment of collective forest resources to households (hereafter referred to as Assignment of Forest); (ii) Sale of forest resources currently held by households, and assignment of the obtained money to households (hereafter referred to as Assignment of Income); (iii) A combination of the two methods above (hereafter referred to as Mixed Method); and (iv) Management of the collective forests as a cooperative business capable of issuing stock, with a village as the unit, by way of joint-stock forest management (hereinafter referred to as Stock Share).

Among the collective forest lands in Fushun City in 2005, 28,500 ha were classified as nature reserves or other special use forests, while management rights for 37,100 thousand ha had already been transferred to nationalized industry or proposed to be allotted to the construction industry, which did not participate in the reform efforts for collective forest rights. This resulted in 596,500 ha of forest lands in Fushun becoming eligible for inclusion in the reform of collective forest rights (FFB 2011).

When Fushun City's collective forest reform effort was initiated in 2005, step-by-step training of forestry staff to be involved in implementing the program was carried out as prescribed in the 2003 national Decision on Forest Development. This policy dictated that after a given province had determined objectives of the reform effort in line with its particular geographic and demographic characteristics, personnel to administer the reform were to be trained in forest bureaus at the provincial and city levels.

The forestry staff were trained on how to effectively implement the reform effort. This involved a thorough review of the purpose and components of the policy; potential ways in which the reforms might be envisioned from the perspective of the farmers' individual situations; effective ways to educate farmers on how the adoption of appropriate silvicultural practices could lead to benefits from the production and sale of products, including trees and understory crops; and a series of steps for explaining elements with which famers might be unfamiliar or might have too little experience, particularly those involving financial transactions and the basic ideas underlying the transfer of use rights. Teams were also trained on field measurement and boundary establishment techniques for forests as well as given a protocol for helping villages to compile informational material for farmers about the forest practices.

The Fushun Forest Bureau allocated six permanent staff members familiar with the reform policies to carry out the reform effort. Three two-person work groups were formed, responsible for villages in Xinbin County, Qingyuan county, and Fushun County and Shuncheng District, respectively. All of these administrative areas fall within the broader boundary of Fushun City. Three villages were randomly selected from forest regions in both Xinbin and Qingyuan Counties, and two each from forested areas of Fushun County and the Shuncheng district of Fushun City proper.

The work teams went directly into each village to direct the village committee in carrying out the reform and provide technical services to the village. Thus reforms in each village were to be directed by the village committee - representing the village as collective forest owner - but under the guidance of the forest reform work teams. As part of the above process, from June 2007 through October 2010 the teams conducted in-depth conversations with 50 farmer households in each of the ten selected villages, gathering information about timber harvesting and/or reforestation activi- 
ties undertaken during the past five years, any silvicultural practices employed, whether they planted herbs or vegetables under their forest canopy, forest breeding, and the like. They also discussed the reform program with farmers, including the aspects related to finances and transfer of use rights as noted previously. A central theme of these interactions centered on the willingness of farmers to change their forest practices given the novel framework established via the reform program.

\section{Resulting structure of rights after the reform}

With the support of the government and the active participation of farmers, from the end of 2005 through 2010, 590,000 ha of collective forest lands in the Fushun City jurisdiction were assigned to households. This amounts to $89 \%$ of the total collective forest land area in the City and $99 \%$ of the collective forest lands eligible for reform during this time. Due to ownership disputes still under investigation, 7500 ha of remaining forest lands were not included in the reform during this period. For

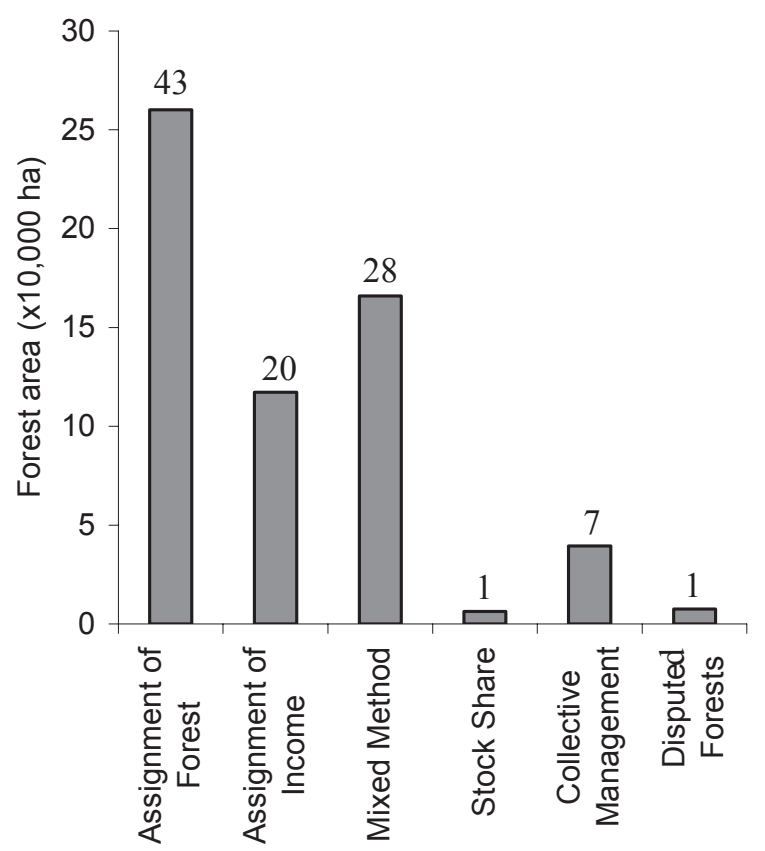

Figure 1 Percentage of forest area in Fushun City after reform by method of assignment (2010). The values above bars represent percents. collective forest lands included in the reform, 39,400 ha are still managed by villages, with income used primarily for public affairs of the village, while the remaining lands were distributed to farmers via the four methods described previously.

As noted earlier, individual farmer households were able to select which of the four methods of assigning collective forest resources to households would be applied to them. The distribution of forest lands previously managed by the collective following the reform by method of assignment may be found in Figure 1. Forty-three percent of farmer households accepted direct assignment of forest rights; while another one-fifth opted to sell their rights for income. About $28 \%$ of farmers chose a combination of these two methods. Shareholder arrangements for forest rights were rare, while $7 \%$ of lands available for rights transfer remained under the management of collectives (Figure 1).

From 2005 to 2010 , a total of 268,800 forest rights certificates were issued, covering 8.67 million ha of collective forest lands or $97 \%$ of such lands eligible for this reform effort. More than 727,000 farmers within 208,000 farmer families participated in the process. Of the 500 single-item questionnaires sent to landowner households visited by the reform team, 482 were returned, for a response rate of $96 \%$. Responses were overwhelmingly positive: 458 $(95 \%)$ of respondent farmer families approved of the reform effort; $4 \%$ were disinterested; and only $1 \%$ disagreed with the reform. The vast majority of farmers supported the reform because they felt they could now better obtain the resources of the forest and access to the means of production, and utilize both as a means toward financial gain. Farmers who did not care about the reform were generally residents of villages with little forest resources. Thus the reform process provided them with no direct benefits in terms access to and potential products from forests, and they often have difficulty in managing what they have. Farm- 
ers who opposed the reform were primarily leaders of township governments and villages. They expressed fear that the transfer of forests from collective to private management would reduce funding available for public welfare programs or that their control over and associated benefits from forests in their jurisdictions would be weakened. Some non-agricultural residents in rural areas also opposed the reform because their own interests are not guaranteed.

After this reform effort, the landscape of forest management in the Fushun City area, previously characterized primarily by national or collectively-managed units, has shifted to one dominated by farmers. The percentage of forest lands managed by farmers $(71.2 \%)$ has almost tripled from that immediately prior to the reform in 2005, while forests managed by collective units has decreased from $55.6 \%$ in 2005 to $8.8 \%$ in 2010 (Table 2, Figure 2). Looking back to the early years of the PRC, the current situation represents an increase in 'private' (i.e., household) forest management in Fushun City from $0 \%$ in 1963 to $71 \%$ in 2010 .

Farmers have also begun to engage in management for multiple uses as, for example, the planting of wild vegetables and Chinese medicinal herbs under the forest canopy. The area of forest lands managed for multiple uses increased by $292 \%$ from 47,800 ha in 2004 (prereform) to 140,000 ha in 2010 (post- reform). This includes a $143 \%$ increase the area of multiple use forests from 2007 to 2009 (Figure 3).

\section{An early assessment of the consequences of rights reform in Fushun City}

A number of positive prospects have resulted from the reform of collective forest rights in Fushun City.

First, forest tenure structures and bases for their retention and transfer have become more explicit and stabilized. The issuance of forest rights certificates and the ability to transfer such rights to others, including heirs, have provided a much needed reduction in the insecurity of forest tenure arrangements that has plagued China's rural populace for decades.

Secondly, through the transfer of the primary functions of forest management to farmers, preconditions have been created to increase their interest and involvement in forest management. Among the information obtained from field interviews with farmers during the latter period of program implementation, farmers were expressing greater awareness of and interest in the potential benefits of conducting forest thinning operations, converting low-yield forests to more productive ones and managing their forests for multiple uses including non-timber forest products.

Thirdly, the reform has created conditions for forestry investments. Prior to the reform, most forest investment originated from collective sources, with a minor contribution from government. With the advent of reform, the government has actively supported forest financing. In 2007, the Fushun government and the city financial agency initiated a program

Table 2 Forest lands by ownership class in Fushun City, 1963-2010

\begin{tabular}{lllllrrr}
\hline Time & $\begin{array}{l}\text { Total } \\
\text { forest } \\
\text { lands }\end{array}$ & $\begin{array}{l}\text { National } \\
\text { forest } \\
\text { lands }\end{array}$ & $\%$ & $\begin{array}{l}\text { Collective } \\
\text { forest lands }\end{array}$ & $\%$ & \multicolumn{2}{l}{$\begin{array}{l}\text { Household } \\
\text { forest lands } \\
\text { or others }\end{array}$} \\
\hline 1963 & 77.96 & 13.94 & 17.9 & 64.02 & 82.1 & 0.00 & 0.0 \\
1975 & 75.23 & 13.76 & 18.3 & 56.90 & 75.6 & 4.57 & 6.1 \\
1984 & 78.84 & 15.79 & 20.1 & 60.40 & 76.6 & 2.61 & 3.3 \\
2005 (before reform) & 82.73 & 16.57 & 20.0 & 45.99 & 55.6 & 20.22 & 24.4 \\
2010 (after reform) & 82.78 & 16.57 & 20.0 & 7.31 & 8.8 & 58.90 & 71.2 \\
\hline
\end{tabular}

Note. Unit: 10,000 ha, Source: Fushun Forestry Bureau, 2011. 


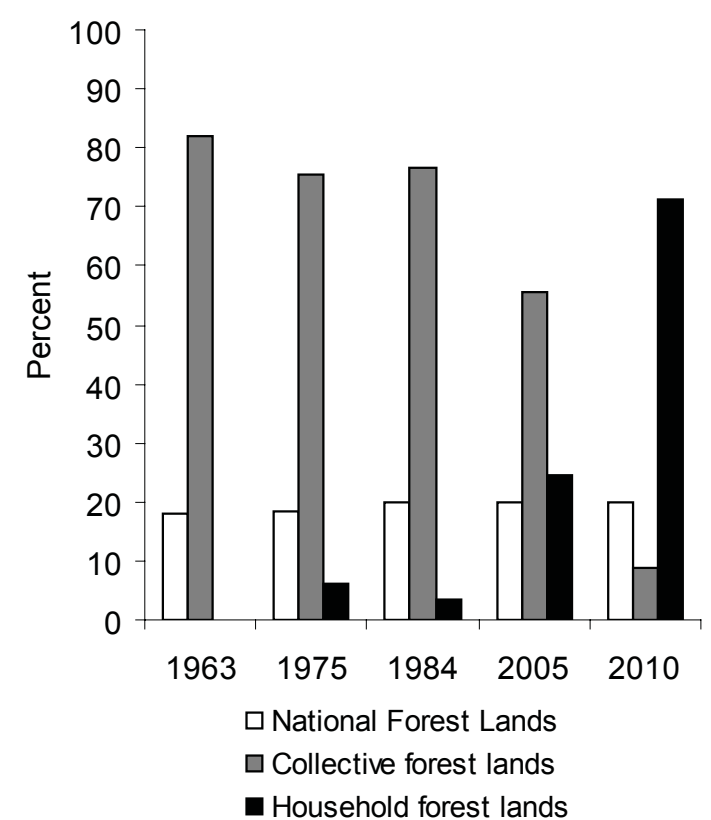

Figure 2 Percent of forest lands in Fushun City by ownership class, 1963-2010

entitled "Management Method for Fushun Forest Rights - Mortgage and Borrow Money" which allows farmers to borrow money from local banks using forests as mortgage. By the end of 2010, banks in Fushun City had issued 758 million RMB (\$115 million) in mortgagebacked loans, of which 672 million RMB (\$104 million) was extended to farmers.

A broader consequence of the reform of forest rights in Fushun City is that the contribution of 'private' (i.e., household-managed) forests to national timber output has increased. The annual harvest quota is a basic component of the Forest Law of the PRC enacted in 1984. Using the county as the basic administrative unit, the national annual harvest quota is determined every 5 years. It serves both as a target for output and an upper limit on the amount of timber that may be harvested from an individual county in a given year. From 2006 to 2010, the annual harvest quota for collective forests in Fushun City was 0.29 million cubic meters (FFB 2011). In 2006, a total of 4918 timber cutting licenses were issued, relative to 5323 farmer families. In 2010, 5349 timber cutting licenses were issued relative to 6819

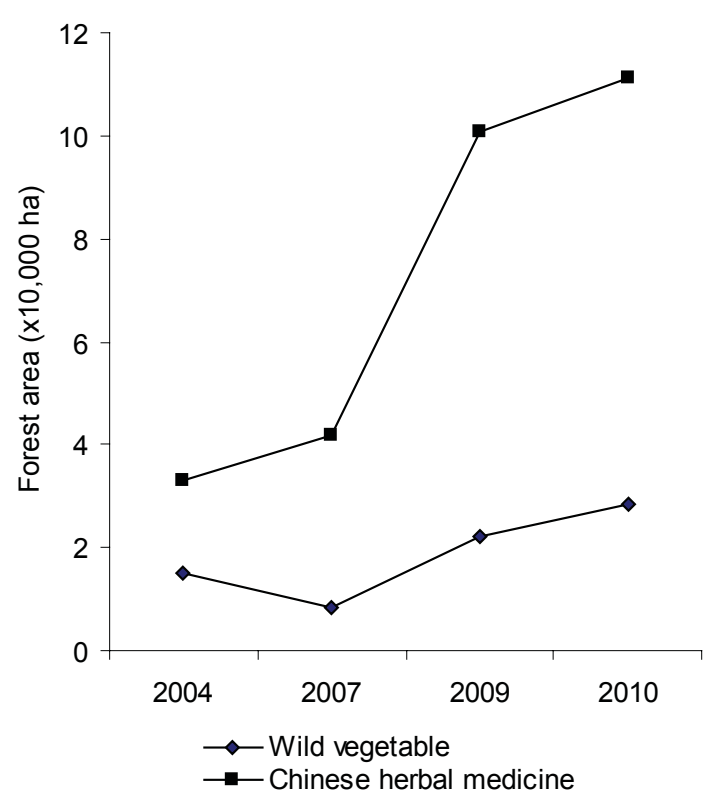

Figure 3 Changes in forest area subject to multiple use management in Fushun City, 20042010

farmer families, a 28\% increase from 2006. Thus with greater autonomy in managing their forests, farmers' contributions toward meeting annual forest quotas have been spread across more forest lands in the area.

Although in the present study we were not able to assess changes in income of farmers with forest lands as a result of reform program, other recent studies of forest tenure reform in China, which included Liaoning province along with others, have found that as farmers acquired direct access to the means of forest production, they concurrently expanded channels for augmenting income. While the total income of farmer families in surveyed provinces increased by $68.2 \%$ from 2005 to 2009 , forest income increased by $113.2 \%$, and forest income as a proportion of total income increased by $6.9 \%$ compared with that before the reform (Liu and Zheng 2009). Areas in which reforms were enacted earlier displayed greater increases in income than did those where reforms were adopted later, suggesting that as farmers became more accustomed to the post-reform environment, the numbers engaging in active forest management increased (Lei and Wen 2009). 


\section{Conclusions}

It is important to recognize that in China most national policies are implemented over a period of years, often in piecemeal fashion and rarely as major reversals or changes in direction from the status quo. This is true for economic policies as well as those that have been the focus of this article, i.e., forest land tenure. It was not until 2003 that support for reform of forest tenure arrangements began to gather substantial momentum at the national level. At that time the State Forest Administration began to actively encourage individual provinces in Southern China to experiment with tenure reform. This policy thrust was extended nationwide by the central government in 2008, and by then Fushun City was already underway with its reform program in Northeast China, a region where public forests dominate.

The Fushun City program has yielded some encouraging initial results in terms of the official transfer and documentation of rights associated with forest tenure as well as the reduction of the historically well-founded insecurity among China's rural population regarding tenure rights for forest lands. A foundation has been established upon which, with increased management autonomy of rural households, both the social welfare of China's rural population and the ecological integrity of the country's forest resources may be enhanced. But these ultimate goals will likely take some time to attain. At this point in time, we conclude that in Fushun City the door to collective forest reform has been opened, but crossing the threshold to social and ecological sustainability still requires resolute and decisive action.

\section{Acknowledgements}

The authors would like to thank the Fushun Forestry Bureau for access to data on the progress of the collective forest reform effort in Fushun City. They also express their ap- preciation to the Forestry Department of Liaoning Province, Shenyang, PRC for helping them appreciate the provincial perspective of the forest tenure reforms underway in Fushun City. Finally, we greatly appreciate the suggestions of the editor and anonymous reviewer(s) regarding both the structure and other details of the article.

\section{References}

Broegaard R., 2005. Land tenure insecurity and inequality in Nicaragua. Development and Change 36(5): 845864. DOI: 10.1111/j.0012-155X.2005.00438.x.

Coase R., Wang N., 2012. How China became capitalist. Palgrave Macmillan, New York. 256 p.

CPC Central Committee and State Council, 2008. Idea about promoting reform of collective forest right system. Beijing. [In Chinese].

Dai L., Zhao W., Shao G., Lewis B., Yu D., Zhou L., Zhou W., 2013. The progress and challenges in sustainable forestry development in China. International Journal of Sustainable Development and World Ecology 20(5): 394-403. DOI: 10.1080/13504509.2013.775193.

Dai L., Wang Y., Su D., Li Z., Yu D., Lewis B.J., Lin Q., 2011. Major forest types and the evolution of sustainable forestry in China. Environmental Management 48: 1066-1078. DOI: 10.1007/s00267-011-9706-4.

Dai L, Zhao F., Shao G., Zhou L., Tang L., 2009. China's classification-based forest management: Procedures, problems, and prospects. Environmental Management 43:1162-117. DOI: 10.1007/s00267-008-9229-9.

Demsetz H., 1967. Toward a theory of property rights. American Economic Review 57(2): 347-359.

Editorial Committee of the Chinese Academy of Sciences. 2001. Atlas of China vegetation. Science Publishing House, Beijing [In Chinese].

FAO, United Nations, 2009. Have decollectivization and privatization contributed to sustainable forestry management and poverty alleviation in China? Forestry Policy and Institutions Working Paper No. 23, Rome.

Forestry Department of Liaoning Province. 2010. Liaoning forest resources. Shenyang, PRC. [In Chinese].

Fushun Forestry Bureau [FFB]. 2010-2011. Liaoning Province, Fushun City, PRC.

General Office of the Liaoning Province People's Government, 2005. Idea about deepening the reform of collective forest property rights. Liaoning Provincial Office, Huanggu District,Shenyang City, China. [In Chinese].

Harrison S.R., Herbohn J.L., Herbohn K.F., 2000. Sustainable small-scale forestry: Social and economic analysis and policy. Edward Elgar, Cheltenham, 247 p.

Jiabao W., 2009. Pay great attention to forestry reform and development. China Forestry Economy. 2009 (5): 6-7. 
Jing H., Shen M., Liu D., 2009. Discussion on the problem of farmers' land-losing after collective forest property transfer in minority areas of Yunnan Province. China Forestry Economy 5: 12-16. [In Chinese].

Kram M., Bedford C., Durnin M., Luo Y., Rokpelnis K., Roth B., Smith N., Wang Y., Yu G., Yu Q., Zhao X., 2012. Protecting China's biodiversity: A guide to land use, land tenure, and land protection tools. Beijing: The Nature Conservancy, $257 \mathrm{p}$.

Lei Z., Wen C., 2008. Impacts of collective forest tenure reform on farmer households' livelihood - an empirical analysis based on Jiangxi, Fujian, Liaoning and Yunnan Provinces. Scienia Silvae Sinicae 44(7). [In Chinese].

Liu D., 2001. Tenure and management of non-state forests in China since 1950: A historical review. Environmental History 6(2): 239-263. DOI: 10.2307/3985086.

Liu W., Zheng X., 2009. Influence of collective forestry property rights system reform on farmers' forestry income. Journal of Fujian Agriculture and Forestry University (Philosophy and Social Sciences) 12(5). [In Chinese].

Naughton-Treves L., Day C., 2012. Lessons about land tenure, forest governance and REDD+. USAID. Madison, Wisconsin: UW-Madison Land Tenure Center.

Oi J., Walder C., 1999. Property rights and economic reform in China. Stanford, CA, Stanford University Press.

Olsson P., Folke C., Berkes F., 2004. Co-management for building social-ecological resilience. Environmental Management 34: 75-90. DOI: 10.1007/s00267-0030101-7.

Schlager E., Ostrum E., 1992. Property rights regimes and natural resources: A conceptual analysis. Land Economics 68: 249-262. DOI: $10.2307 / 3146375$.

SFA (State Forestry Administration). 2010. Condition of forest certification in the world. Web: http://www/forestry.gov.cn/portal/main/s/241/content-443812.html. Accessed: 04.2014. [In Chinese].

SFA (State Forestry Administration), 2009. The 7th National Forest Inventory. Beijing, SFA. [In Chinese].

Shang F., Lu Z., Yao R., 2009. The effective analysis of reforms of collective forest ownership systems in Benxi City. Liaoning Forestry Science and Technology (5). [In Chinese].

Social Sciences Institute of Fushun City, Records Office of Fushun Government. 2011. "Fushun Yearbook “, Liaoning Ethnic Publishing House. [In Chinese]

Walder A., Oi J., 1999. Property rights in the Chinese economy: Contours of the process of change. In: Oi J., Walder A., (eds.), Property rights and economic reform in China. Stanford University Press, pp. 1-24.

Wang G.Y., Innes J.L., Lei J.F., Dai S.Y., Wu S.W., 2007. China's forestry reforms. Science 318: 1556-1557. DOI: $10.1126 /$ science. 1147247.

World Bank, 2013. The state of the poor: Where are the poor and where are they poorest? Washington, D.C.

Xu J., Siikamäki J., 2012. Forest Tenure Reform in China. Resources (Magazine) 180, Resources for the Future, Washington, D.C.

Xu J., White A., Lele U., 2010. China's forest tenure reforms. Rights \& Resources Initiative, Washington, D.C., $20 \mathrm{p}$

Yang J., 2012. Tombstone. Farrar, Straus \& Giroux, New York. 629 p. 